\title{
Comparative Study on the Need for Postoperative Analgesic Medication After Surgical Treatment of Inguinal Hernia with Surgical Mesh through Laparoscopic or Classic Approach
}

\author{
BOGDAN ANDREI SUCIU1,2, IOANA HALMACIU1*, DECEBAL FODOR ${ }^{1,2}$, CRISTIAN TRAMBITAS ${ }^{1}$, DUMITRU GODJ A2, \\ ADRIANA CLIPA ${ }^{3}$, COSMIN NICOLESCU ${ }^{1}$, KLARA BRINZANIUC ${ }^{1}$, VLAD VUNVULEA ${ }^{1}$ \\ ${ }^{1}$ University of Medicine and Pharmacy Tirgu Mures, Department of Anatomy, 38 Gheorghe Marinescu Str., 540142, Tirgu Mures, \\ Romania \\ 2Department of Surgery, University of Medicine and Pharmacy Tîrgu Mures, 50 Gheorghe Marinescu Str., 540136,Tirgu Mures, \\ Romania \\ ${ }^{3}$ Ovidius University Constana, Faculty of Medicine, 124 Mamaia Blvd., 900527, Constanta, Romania
}

The incidence of postoperative pain in patients operated for inguinal hernia can reach up to $40 \%$ of cases, depending on different authors, and depending on the approach used in the surgical treatment of these patients. Currently, there are two commonly accepted ways of surgical treatment of inguinal hernias, the classic approach with polypropylene mesh (Liechtenstein technique) and the laparoscopic approach. The purpose of this study was to conduct a comparative analysis on the need for analgesic medication in patients treated for inguinal hernia either by classic (group A) or by laparoscopic (group B) approach. Surgical meshes were used in all patients enrolled in our trial. The average age of the patients included in this study was 53.79 years, ranging from 20 to 88 years. Regarding the distribution of cases by gender, we observed in the studied lots that 12 cases were women (11.53\%) and 92 cases were males (88.46\%). In female patients, the classic inguinal hernia approach was performed in 3 cases (25\% of cases), and in 9 cases the laparoscopic approach was performed in the surgical treatment of the inguinal hernia (75\% of the cases). In male patients, laparoscopic approach was performed in 33 cases (35.86\% of cases), and in 59 cases the surgical approach was performed in a classical manner using the Liechtenstein technique $164.13 \%$ of the cases). From the statistical analysis of the data we noticed a statistically significant difference in the need for analgesic medication administered to these patients $(p=0.0001)$. Although surgical correction of inguinal hernia, both classic and laparoscopic approaches, provide adequate treatment for these patients, in case of the laparoscopic technique, immediately after the operation, the need for analgesic medication is lower compared to the classical technique

Keywords: polypropylene, self gripping mesh, analgesic treatment

Surgical abdominal wall surgery for inguinal hernia is one of the most common surgical interventions in general surgery clinics. Although there are relatively simple surrgical procedures, postoperative complications that may occur in these patients may affect their prognosis [1]. One of the major co-morbidities that can occur in patients undergoing surgery is postoperative pain. The occurrence of postoperative pain can influence the prognosis of the patients operated due to the fact that, in addition to its psychosomatic implications, the occurrence of postoperative pain may prolong the postoperative healing of patients as well as their social reinsertion [2]. The incidence of acute postoperative pain in patients treated for inguinal hernia can reach up to $40 \%$ of cases, depending on different authors, and the surgical approach used in the treatment of these patients [3]. Currently there are two unanimously accepted ways of surgical treatment of inguinal hernia, the classic approach with polypropylene mesh (Liechtenstein technique) and the laparoscopic approach. Each technique has its advantages and disadvantages, as there is currently no unanimous consensus on a particular surgical technique.

Postoperative analgesic treatment can be given to these patients either generally or locally as infiltrates [4]. The most common analgesic drugs used in the treatment of postoperative pain in patients with operated inguinal hernia are: acetaminophen, non-steroid anti-inflammatory drugs and opioid medication. Since these surgical interventions are relatively minor, it is suggested to avoid the use of opioid medication in the treatment of postoperative pain in these patients due to the severe systemic complications that may occur when using it [5].

\section{Experimental part}

The purpose of this study was to analyse the need for analgesic medication in patients operated for inguinal hernia, both by classical approach and by laparoscopic approach. In this regard, we performed a retrospective observational study over a period of 1 year, in which we introduced 104 patients, operated for inguinal hernia in the Surgery Clinic No. 1 of Tirgu Mures University Hospital. The 104 patients were divided into 2 groups: group A consisting of 62 were the surgical treatment of the inguinal hernia was done using the Liechtenstein technique (with polypropylene mesh or Progrip ${ }^{\mathrm{TM}}$ mesh) and B group consisting of 42 patients who underwent surgical cure of the inguinal hernia by laparoscopic approach (TAPP technique - transabdominal preperitoneal patch plasy).

In all patients included in the trial, Algocalmin ${ }^{\mathrm{TM}} 2 \mathrm{~mL}$ ampoules were administered intravenously or intramuscularly ( $1 \mathrm{~g}$ metamizole sodium monohydrate) as post-operative analgesic medication. The administration of the analgesic medication was not routine or prophylactic, only at the patient's request, depending on

*email : anca_halmaciu@yahoo.com; Phone: 0040740091324 
the presence or absence of pain. Also, to improve the results of our study, we excluded from the trial patients who were given other types of analgesics in order not to influence the statistical analysis. In our study we were only interested in the treatment of acute postoperative pain, occurring in the immediate postoperative period, not in the treatment of chronic pain.

The clinical data needed to conduct our study was obtained from the hospital's integrated computer system, based on the fact that analgesic medication administered to patients was entered in this computer network system. To get the highest data accuracy, we only included patients in our study who were discharged from the clinic on the 2nd postoperative day. The statistical analysis of the data was done using the Microsoft Excel ${ }^{\mathrm{TM}}$ and GraphPad ${ }^{\mathrm{TM}}$ software.

\section{Results and discussions}

The average age of the patients included in the trial was 53.79 years, ranging from 20 to 88 years. Regarding the distribution of cases by gender, we observed that 12 patients were women (11.53\%) and 92 patients were male (88.46\%). We have also studied the distribution of different types of surgical approaches depending on the gender of the patients. We noticed that in the case of female patients the classic inguinal hernia approach was performed in 3 cases ( $25 \%$ of the cases), and in 9 cases the laparoscopic approach was performed in the surgical treatment of inguinal hernia ( $75 \%$ of the cases). In male patients, laparoscopic approach was performed in 33 patients (35.86\% of cases), and in 59 cases the surgical approach was performed in a classical manner using the Liechtenstein technique (64.13\% of the cases) (fig. 1). It can be noticed that, from the point of view of the proportion of types of surgical approaches based on the gender of the patients, the proportion of laparoscopic approach in female patients was higher compared to males.

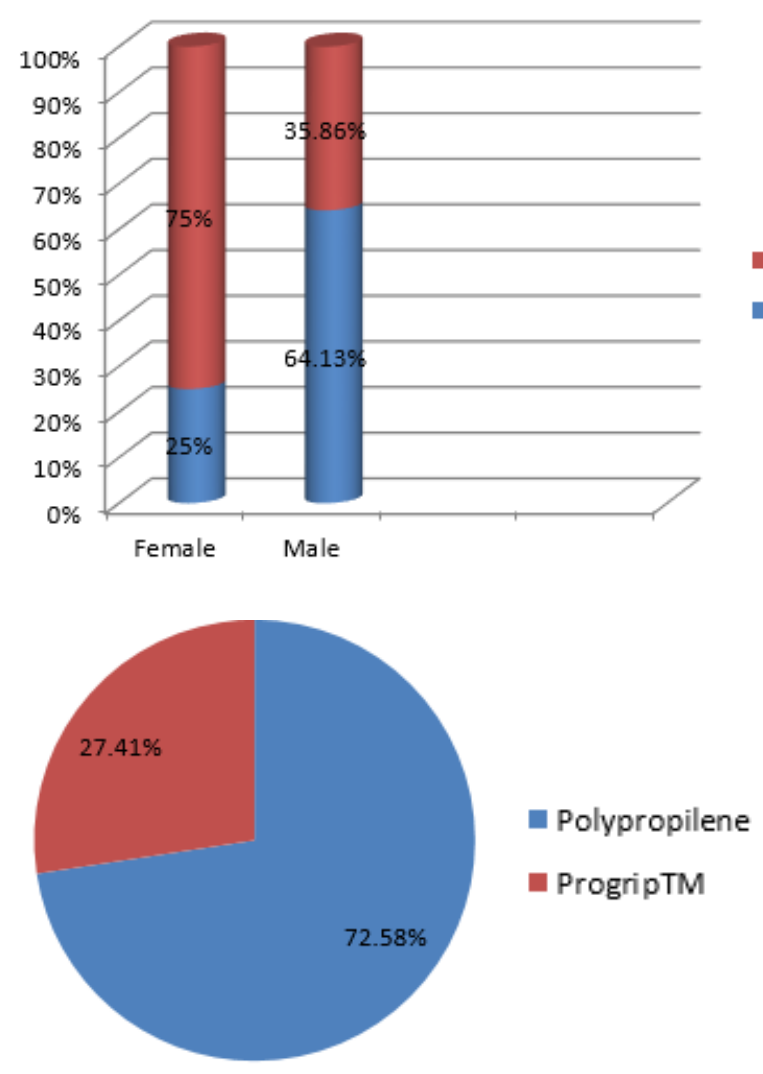

Fig. 2. Types of meshes used in lot $A$
In group $A$, we noticed that 2 types of surgical meshes were used: the polypropylene mesh was used in 45 patients ( $72.58 \%$ of cases) and the ProGrip ${ }^{\mathrm{TM}}$ mesh was used in 17 patients (27.41\% of cases) (fig. 2). ProGrip ${ }^{T M}$ has the advantage of having a much better tissue integration compared to polypropylene mesh. Instead, it has the disadvantage of being much more expensive.

We have further analysed the need for analgesic medication in the patients studied. To achieve this goal, we evaluated the number of sodium metamizole monohydrate ampoules administered to each patient on both the day of surgery and the first and second postoperative days. We studied the need for analgesic medication only in the first 3 days because on average the patients operated for inguinal hernia on the 2nd postoperative day are discharged from our clinic. Thus, on the day of surgery we noticed that, in case of group A (patients where the classical approach was used), 5 patients did not receive analgesic medication $(8.06 \%$ of the cases), 24 patients received $1 \mathrm{~g}$ of Metamizole sodium (38.70\% of cases), 29 patients received $2 \mathrm{~g}$ of Metamizole sodium ( $46.77 \%$ of cases) and 4 patients received $3 \mathrm{~g}$ of Metamizole sodium ( $6.45 \%$ of cases). In group B (patients where the laparoscopic approach was used), 34 patients did not receive analgesic medication on the day of surgery ( $80.95 \%$ of cases), and 8 patients received $1 \mathrm{~g}$ Metamizole sodium (19.04\% of cases) (fig. 3). Itcan already be observed that on the day of the surgery, patients from group $B$ required less analgesic medication compared to patients from group A.

On the first postoperative day, we noticed that, in case of group A, 25 patients did not receive analgesic medication ( $40.32 \%$ of cases), 4 patients received $1 \mathrm{~g}$ sodium metamizole (6.45\% of cases), 2 patients received $2 \mathrm{~g}$ sodium metamizole (3.22\% of cases) and 31 patients received $3 \mathrm{~g}$ of Metamizole sodium (50\% of cases). For group $B, 26$ patients did not receive analgesic medication on the first postoperative day (61.90\% of cases), 1 patient

Fig. 1. Distribution of the types of surgical interventions according to the gender
Classic approach

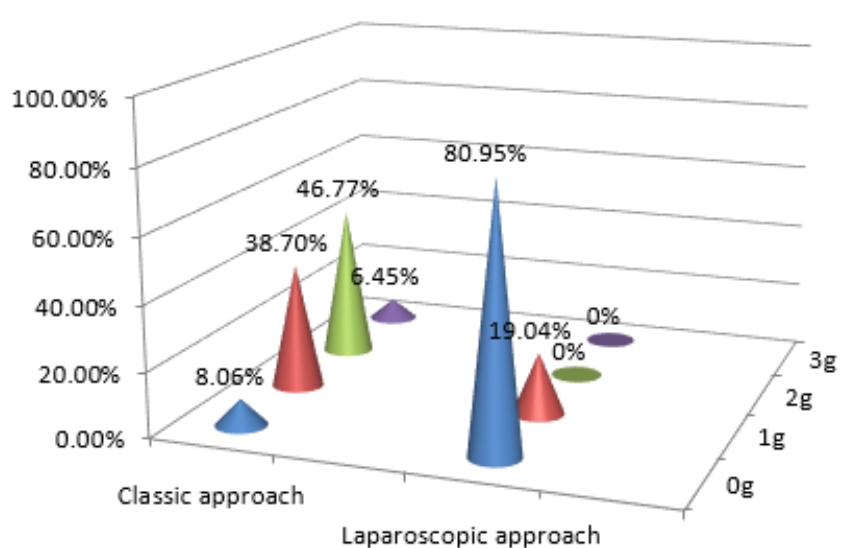

Fig. 3. The need for analgesic medication on the day of surgery 


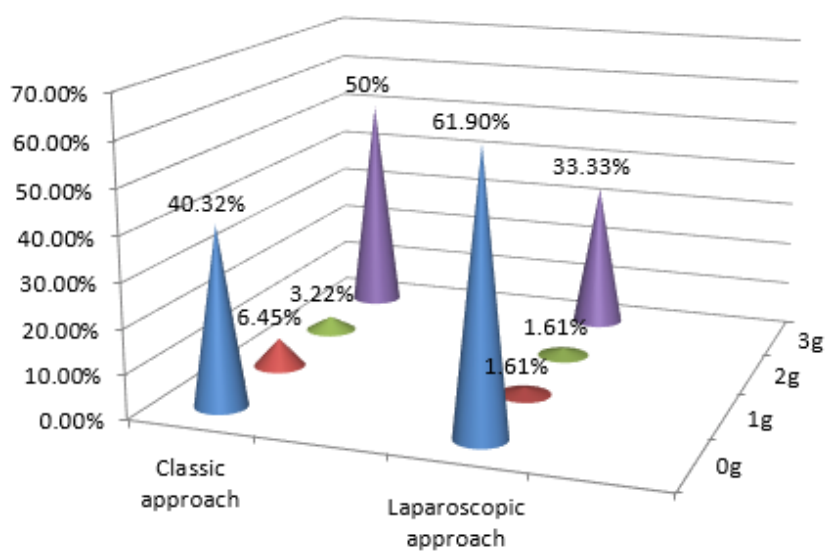

Fig. 4. The need for analgesic medication on the first postoperative day

received $1 \mathrm{~g}$ Metamizole sodium (1.61\% of cases), 1 patient received $2 \mathrm{~g}$ Metamizole sodium ( $1.61 \%$ and 14 patients received $3 \mathrm{~g}$ of Metamizole sodium (33.33\% of cases) (fig. 4).

During the second postoperative day, we noticed that 29 patients did not receive analgesic medication (46.77\% of cases), 2 patients received $1 \mathrm{~g}$ sodium metamizole (3.22\%), 2 patients received $2 \mathrm{~g}$ of metamizole sodium (3.22\% of cases) and 29 patients received $3 \mathrm{~g}$ of Metamizole sodium ( $46.77 \%$ of cases). In group B, 30 patients did not receive analgesic medication ( $71.42 \%$ of cases), 1 patient received $2 \mathrm{~g}$ Metamizole sodium (1.61\%), and 11 patients received $3 g$ Metamizole sodium (26.19\%) (fig. 5). It can be noticed that in case of group $B$, a relatively large proportion of patients did not require analgesic medication.

We then tried to study separately, according to the two lots, the total amount of analgesic medication that patients received during hospitalization. In this respect, we calculated the total number of grams of metamizole sodium monohydrate received by patients during hospitalization. It can be noticed that, in the case of lot $B$, the need for analgesic medication was much lower. The results are presented in table 1.

We then performed the statistical analysis of the data obtained. We were mainly interested in statistically significant differences in the need for analgesic medication during hospitalization, and we noticed that there are significant results between lot $A$ and group $B$ in terms of need for analgesic medication ( $p=0.0001$ ), the need for analgesic medication being higher for lot $A$. The results are presented in figure 6 .

We also tried to establish whether there is a statistically significant difference in the need for analgesic medication for the two types of surgical meshes used (Polypropylene and Progrip $p^{T M}$. We did not obtain statistically significant differences $(p=0.878)$. This result proves that the differences between the need for analgesic medication recorded between group $A$ and group $B$ are due to differences in surgical technique and not due to differences in the type of mesh used. The results are shown in figure 7.

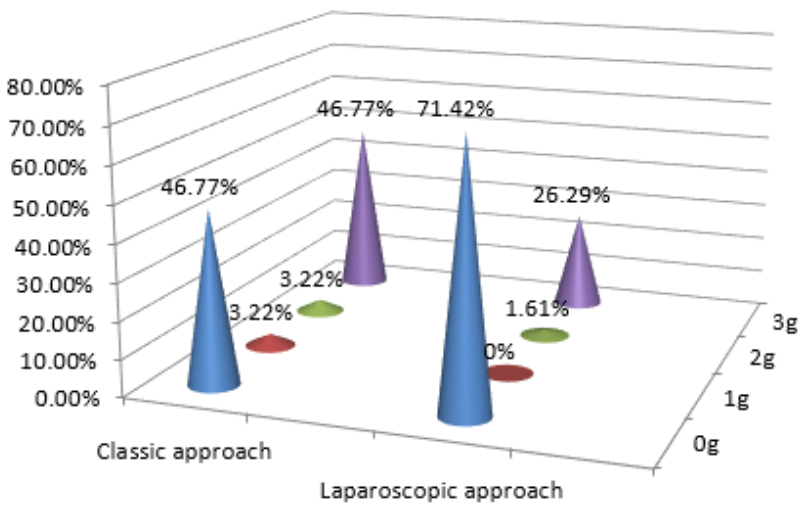

Fig. 5. Need for analgesic medication on the second postoperative day

The results of our study confirm the results of other authors in the literature who observed that after the laparoscopic approach of the inguinal hernia, the incidence of postoperative pain as well as the need for analgesic medication is lower compared to instances where surgical treatment of hernia was practiced using a classic approach $[6,7]$.

Currently, surgical treatment of the inguinal hernia is one of the most common surgical interventions practiced, more than 20 million such surgeries being performed each year worldwide $[8,9]$. In the surgical treatment of inguinal hernia, 3 different types of surgical techniques are currently used: the classic approach by the Liechtenstein technique, the laparoscopic approach by the transabdominal preperitoneal approach (TAPP) and the laparoscopic approach by TEP (totally extraperitoneal approach). In the long term it has been confirmed that there are no major differences in the incidence of herniated relapse in all three types of surgery or patient satisfaction even though the classic approach is particularly preferred in elderly patients with comorbidities [10,11].

Although the technique used in the surgical treatment of an inguinal hernia is currently considered a relatively ordinary procedure, a fairly large number of patients in the postoperative period have a relatively high incidence of postoperative pain. This is mainly due to the relatively increased inguinal innervation of the inguinal region. Three sensitive nerves can be identified at the level of the inguinal canal: the ilioinguinal nerve, the iliohipogastric nerve and the genital branch of the genitofemoral nerve $[12,13]$.

Many authors recommend in order to prevent postoperative pain, especially chronic pain, to identify and manage the three nerves during surgery. This is not always easy to achieve because of local anatomical variations, on the other hand, these nerves often have an aberrant trajectory. In this regard, some authors have shown that during the inguinal hernia surgery, only in about $30-40 \%$ of the cases all three nerves of the inguinal canal are identified $[14,15]$.

\begin{tabular}{|l|l|l|}
\hline Sodic metamizole & \multicolumn{1}{|c|}{ Lot A } & \multicolumn{1}{|c|}{ Lot B } \\
\hline $0 \mathrm{~g}$ & 2 patients(3.22\% of cases) & - \\
\hline $1 \mathrm{~g}$ & 12 patients(19.35\% of cases) & 23 patients(54.76\% of cases) \\
\hline $2 \mathrm{~g}$ & 13 patients(20.96\% of cases) & 5 patients(11.90\% of cases) \\
\hline $3 \mathrm{~g}$ & 2 patients(3.22\% of cases) & - \\
\hline $4 \mathrm{~g}$ & 1 patient (1.61\% of cases) & 3 patients(7.14\% of cases) \\
\hline $6 \mathrm{~g}$ & 5 patients(8.06\% of cases) & 1 patient (2.38\% of cases) \\
\hline $7 \mathrm{~g}$ & 8 patients(12.90\% of cases) & 8 patients(19.04\% of cases) \\
\hline $8 \mathrm{~g}$ & 16 patients(25.80\% of cases) & 2 patients(4.76\% of cases) \\
\hline $9 \mathrm{~g}$ & 1 patient (1.61\% of cases) & - \\
\hline $10 \mathrm{~g}$ & 1 patient (1.61\% of cases) & - \\
\hline $12 \mathrm{~g}$ & 1 patient (1.61\% of cases) & - \\
\hline
\end{tabular}

Table 1

ANALGESIC MEDICATION RECEIVED BY PATIENTS DURING ADMISSION 


\begin{tabular}{|c|c|c|c|c|}
\hline Table Analyzed & Unpaired $t$ test data & & & \\
\hline Column B & Clasic & Number of values & 62 & 42 \\
\hline vs. & vs. & & & \\
\hline \multirow[t]{2}{*}{ Column A } & Laparoscopic & Minimum & 0 & 1 \\
\hline & & $25 \%$ Percentile & 2 & 1 \\
\hline Unpaired $t$ test & & Median & 6 & 1 \\
\hline $\begin{array}{l}\text { P value } \\
P \text { value summary }\end{array}$ & $\cdots$ & $75 \%$ Percentile & 8 & 2 \\
\hline Significantly different $(P<0.05)$ ? & Yes & Maximum & 10 & 8 \\
\hline One- or two-tailed P value? & Two-tailed & & & \\
\hline t, df & $t=3.946 \mathrm{df}=100$ & Mean & 4.607 & 2.341 \\
\hline How big is the difference? & & Std. Deviation & 3.111 & 2.383 \\
\hline Mean \pm SEM of column A & $4.607 \pm 0.3983, n=61$ & Std. Error of Mean & 0.3983 & 0.3722 \\
\hline Mean \pm SEM of column B & $2.341 \pm 0.3722, n=41$ & & & \\
\hline Difference between means & $-2.265 \pm 0.574$ & Lower $95 \% \mathrm{Cl}$ of mean & 3.81 & 1.589 \\
\hline $\begin{array}{l}\text { 95\% confidence interval } \\
\text { R squared (eta squared) }\end{array}$ & -3.404 to -1.126 & Upper $95 \% \mathrm{Cl}$ of mean & 5.403 & 3.094 \\
\hline F test to compare variances & & Coefficient of variation & $67.53 \%$ & $101.79 \%$ \\
\hline F, DFn, Dfd & $1.703,60,40$ & & & \\
\hline $\begin{array}{l}P \text { value } \\
P \text { value summary }\end{array}$ & 0.0759 & Sum & 281 & 96 \\
\hline Significantly different $(P<0.05)$ ? & No & & & \\
\hline
\end{tabular}

rıg. 6. Statıstıcal analysıs of the need tor analgesıc medıcatıon between Iot $\mathrm{A}$ and Iot $\mathrm{B}$

\begin{tabular}{|c|c|c|c|c|}
\hline Clasic & & Number of values & 45 & 17 \\
\hline Table Analyzed & \multicolumn{4}{|l|}{ Unpaired $t$ test data } \\
\hline Column B & Progrip & Minimum & 0 & 0 \\
\hline vs. & vs. & 25\% Percentile & 2 & 1 \\
\hline Column A & Polipropilena & Median & 6 & 2 \\
\hline $\begin{array}{l}\text { Unpaired } t \text { test } \\
\text { P value }\end{array}$ & 0.0878 & $75 \%$ Percentile & 8 & 7 \\
\hline P value summary & ns & Maximum & 12 & g \\
\hline $\begin{array}{l}\text { Significantly different }(P<0.05) ? \\
\text { One- or two-talled } P \text { value? }\end{array}$ & $\begin{array}{l}\text { No } \\
\text { Two-tailed }\end{array}$ & & & \\
\hline \multirow[t]{2}{*}{$\mathrm{t}, \mathrm{df}$} & $t=1.735 d f=60$ & Mean & 5.156 & 3.588 \\
\hline & & Std. Deviation & 3.183 & 3.144 \\
\hline $\begin{array}{l}\text { Mean } \pm \text { SEM of column } A \\
\text { Mean } \pm \text { SEM of column } B\end{array}$ & $5.156 \pm 0.4746, n=45$ & Std. Error of Mean & 0.4746 & 0.7624 \\
\hline $\begin{array}{l}\text { Mean } ₫ \text { SEM of column } 8 \\
\text { Difference between means }\end{array}$ & $-1.567 \pm 0.9033$ & & & \\
\hline $\begin{array}{l}\text { 95\% confidence interval } \\
\text { R squared (eta squared) }\end{array}$ & $\begin{array}{r}-3.374 \text { to } 0.2395 \\
0.04778\end{array}$ & Lower $95 \% \mathrm{Cl}$ of mean & 4.199 & 1.972 \\
\hline R squared (eta squared) & & Upper $95 \% \mathrm{Cl}$ of mean & 6.112 & 5.205 \\
\hline F, DFn, Dfd & $1.025,44,16$ & & & \\
\hline $\begin{array}{l}\text { P value } \\
\text { P value summary }\end{array}$ & $\begin{array}{l}>0.9999 \\
\text { ns }\end{array}$ & Sum & 232 & 61 \\
\hline Significantly different $(P<0.05) ?$ & No & & & \\
\hline
\end{tabular}

rıg. I. Statıstıcal analysıs of the ditterence in the need tor analgesıc medicatıon between the two types of meshes used

One of the major goals of the postoperative treatment is to achieve proper pain control. It is known that persistent postoperative pain may increase the morbidity and even the mortality of surgical interventions [16-19]. In cases of postoperative pain in inguinal hernia patients, there are currently three therapeutic options: treatment with minor analgesics (including non-steroidal anti-inflammatory drugs), opioid treatment and loco-regional anesthesia techniques [20-22]. In our study, we attempted to use only minor analgesic therapy because the other two therapeutic approaches involve higher risks for patients.

The use of the anesthetic blocks (of the iliohypogastric or ilioinguinal nerves), both during surgery and during the postoperative period, has the advantage that they significantly reduce the need for postoperative analgesic medication, but instead require an anesthetic technique which in some cases can be laborious, and not widely practiced in all medical centers [23-25].
There are authors who have tried in the case of postoperative pain in patients operated for an inguinal hernia, the infiltration of the postoperative wound with local anesthetics. Administration of these substances can be done subcutaneously or subfascial. In the case of subcutaneous injection, the results are contradictory because there are studies that have shown the effectiveness of the method butalso studies that contradict these results $[26,27]$. In contrast, in the case of local subfascial anesthetic injection, the vast majority of studies show the superiority of this analgesic medication technique $[28,29]$.

\section{Conclusions}

Although in the case of surgical treatment of an inguinal hernia, both classic and laparoscopic approaches ensure adequate surgical cure of these patients, in the case of laparoscopic approach, in the immediate postoperative 
period, the need for analgesic medication is lower compared to the classical approach.

\section{References}

1.KAMAL K., JAIN P., BANSAL T., AHLAWAT G., Indian. J. Anaesth., 62,2018,nr.4,p.292-297

2.ALFIERI S., AMID PK., CAMPANELLI G., IZARD G., KEHLET H., WIJSMULLER AR., DI MICELI D., DOGLIETTO GB., Hernia; 15,2011,nr.3,p.239-249

3.BAY-NIELSEN M., PERKINS FM., KEHLET H., DANISH HERNIA DATABASE., Ann. Surg., 233,2001,nr.1,p.1-7

4.SUJATHA C., ZACHARIAH M., RANJAN RV., GEORGE SK., RAMACHANDRAN TR., PILLAI AR., Anesth. Essays. Res., $11,2017, \mathrm{nr} .4, p .976-980$

5.WHITE PF., KEHLET H., Anesthesiology., 112,2010,nr.1,p.220-225 6.HERNIASURGE GROUP, Hernia., 22,2018,nr.1,p.1-165

7.BUD V., SUCIU BA., BUTIURCA V., BRINZANIUC K., COPOTOIU R., COPOTOIU C., SIN A., Rom. J. Morphol. Embryol., 54,2013,nr.1,p.115119

8.KINGSNORTH A., LEBLANC K., Lancet., 362,2003,nr.8,p.1561-1571 9.ROMAIN B., GILLION JF., ORTEGA-DEBALLON P., MEYER N., CLUB HERNIE., Hernia 2018, doi: 10.1007/s10029-018-1796-y.

10.LIECHTENSTEIN IL., SHULMAN AG., AMID PK., MONTLOR MM., Am. J. Surg., 155,1988,nr.6,p.786-790

11.TRAMBITAS, C., POP, TS., TRAMBITAS, MIRON AD., DOROBANTU, DC., BRINZNIUC, K., Rev. Chim.(Bucharest), 68, no. 2, 2017, p.387389

12.VAN HANSWIJCK DE JONGE P., LLOYD A., HORSFALL L., TAN R., O'DWYER., Hernia., 12,2008,nr.6,p.561-569

13.WIJ SMULLER AR., LANGE JF., VAN GERLDERE D., SIMONS MP., KLEIRENSINK GJ ., HOP WC., JEEKEL J., LANGE J F., Hernia., 2,2007,nr.11,p.147-151

14.KEHLET H., HOLTE K., Br. J. Anaesth., 87,2001,nr.1,p.62-72

15.SUCIU BA., HALMACIU I., VUNVULEA V., BRINZANIUC K., Eur. J. Cardiothorac. Surg., 53,2018,nr.4,p.895-896
16.SHARMA UD., PRATEEK, TAK H., Indian. J. Anaesth., 62,2018,nr.5,p.371-375

17.DEMIRCI A., EFE EM., TURKER G., GURBET A., KAYA FN., ANIL A., CIMEN I., Rev. Bras. Anestesiol., 64,2014,nr.5,p.350-356

18.DUSA, FS., BADAU, A., BADAU, D., TRAMBITAS, C., BRINZANIUC, K., Mat.Plast., 54, no. 4, 2017, p. 606-609

19.LOSTUN, G., LOSTUN, A., HAINAROSIE, R., PIETROSANU, C., MANOLESCU, A., BRINZANIUC, K., Rev. Chim.(Bucharest), 67, no. 6, 2016,p.1183-1185

20.ANDERSEN FH., NIELSEN K., KEHLET H., Br. J. Anaesth., 94,2005,nr.4,p.520-523

21.MURESAN M., MURESAN S., BARA T., BRINZANIUC K., SALA D., SUCIU B., RADU N., Ann. Ital. Chir., 86,2015,p.421-426

22.SUCIU BA., PAP Z., DENES L., BRINZANIUC K., COPOTOIU C., PAVAI Z., Rom. J. Morphol. Embryol., 57,2016,nr.2,p.495-500

23.DING Y., WHITE PF., Can. J. Anaesth., 42,1995,nr.1,p.12-15

24.SUCIU, BA., HALMACIU, I., BUD, V., COPOTOIU, C., FODOR, D., TRAMBITAS, C., GODJA ,D., VUNVULEA, V., MOLNAR, C., BRINZANIUC, K., Mat. Plast. 54, no. 4,2017, p.626-629

25.SUCIU, BA., HALMACIU, I., BUD, V., COPOTOIU, C., FODOR, DRP., TRAMBITAS, C., VUNVULEA, V., MOLNAR, C., BRÎNZANIUC, K., Mat. Plast. 54, no. 3. 2017, p.520-522

26.AUSEMS ME., HULSEWE KW., HOGYMANS PM., HOOFWIJK AG., Anaesthesia., 62,2007,nr.4,p.325-331

27.KURMANN A., FISCHER H., DELL-KUSTER S., ROSENTHAL R., AUDIGE L., SCHUPFER G., METZGER J., HONIGMANN P., Surgery., 157,2015, nr.1,p.144-154

28.YNDGAARD S., HOLST P., BJ EERE-JEPSEN K., THOMSEN CB., STRUCKMANN J., MOGENSEN T., Anesth. Analg., 79,1994,nr.2,p.324327

29.EL-RADAIDEH KM., AL-GHAZO MA., BANI-HANI KE., Asian. J. Surg., 29,2006,nr.4,p.242-246

$\overline{\text { Manuscript received: } 11.06 .2018}$ 